\title{
Spectroscopic Determination of Metal-Ligand Coordination by Biologically Active 2-Picolinehydroxamic Acid with Iron(III) and Oxidovanadium(IV) in Aqueous Solutions
}

\author{
Magdalena Woźniczka, ${ }^{1,}$ Mirosława Świątek, ${ }^{1}$ Joanna Gądek-Sobczyńska, ${ }^{1}$ \\ Beata Pasternak ${ }^{2}$ and Aleksander Kufelnicki ${ }^{1}$ \\ ${ }^{1}$ Department of Physical and Biocoordination Chemistry, Faculty of Pharmacy, Medical University of Lodz, \\ Muszyńskiego 1, 90-151 Lodz, Poland \\ ${ }^{2}$ Department of Organic Chemistry, Faculty of Chemistry, University of Lodz, Tamka 12, 91-403 Lodz, Poland \\ *Corresponding author: E-mail: magdalena.wozniczka@umed.lodz.pl
}

Received: 04-11-2019

\begin{abstract}
The complexing properties of 2-picolinehydroxamic acid towards iron(III) as well as oxidovanadium(IV) were characterized in aqueous solutions by the UV-Vis spectrophotometric method. The speciation models have been confirmed and even extended by electrospray-ionization mass spectrometry (ESI-MS) studies. For both systems, mononuclear complexes were formed below a $\mathrm{pH}$ of 1 and coordination by $\left\{\mathrm{O}, \mathrm{O}^{-}\right\}$chelation mode leading to the formation of five-membered rings was confirmed. The overall stability constant values were determined and compared with other similar systems, indicating more effective binding of the ligand by $\mathrm{Fe}(\mathrm{III})$ than $\mathrm{VO}(\mathrm{IV})$. The acidic medium of the reaction in the $\mathrm{VO}(\mathrm{IV})$ - 2-picolinehydroxamic acid system prevented the oxidation of $\mathrm{VO}(\mathrm{IV})$ to $\mathrm{V}(\mathrm{V})$. 2-Picolinehydroxamic acid was chosen because of its previously evidenced biological properties. As a result of acidification, reversible dissociation of the complexes in both systems was observed, indicating the action of 2-picolinehydroxamic acid as a potential siderophore.
\end{abstract}

Keywords: Iron(III) complexes; oxidovanadium(IV) complexes; 2-picolinehydroxamic acid; UV/Vis spectroscopy; ESIMS spectroscopy

\section{Introduction}

Metal ions and their complexes have a significant impact on biological systems. Therefore, it is extremely important to analyze the detailed structure and composition of these compounds, especially since their application as therapeutic agents is constantly increasing. ${ }^{1}$ The iron is important ion for catalyzing oxidoreductase reactions ${ }^{2,3}$ and playing a key role in cellular respiration. ${ }^{4}$ This metal is found in many essential metalloproteins ${ }^{5}$ and is a nutrient of microorganisms, provided in the form of iron(III)-siderophore complex. ${ }^{6,7}$

Not any less interesting transition metal is vanadium, present mainly in the body as the oxidovanadium(IV) ion, potentially an inhibitor of phosphatases, phosphotransferases, nucleases and kinases, ${ }^{8-10}$ acting as an essential cofactor in two classes of enzymes, haloperoxidases and nitrogenases, probably also in a third class, vanabins. ${ }^{4,5}$ Based on vanadium as an insulin mimetic agent, the drugs have been proposed for treatment of diabetes. ${ }^{11-13}$

The potentially toxic effects of iron and vanadium led to a permanent search for ligands binding excess metal ions. ${ }^{5,11}$ A characteristic feature of most of the hydroxamic acids is their ability to form very stable complexes with iron(III) ${ }^{15,16}$ and oxidovanadium(IV).${ }^{17}$ As a result, the determination of formation constants is often impossible by $\mathrm{pH}$-potentiometry, particularly when complexation occurs in a strongly acidic medium. However, the metal-hydroxamic acid interaction might be quite well characterized by UV-Vis electronic absorption bands and is supported by ESI-MS spectroscopy. Some natural hydroxamic acids exist as siderophores and are responsible for iron transport to microbial cells. ${ }^{18-20}$ In addition, hydroxamic acids showing a strong interaction with metal ions have 
been used to treat anemia, remove excess iron ions and serve as inhibitors. ${ }^{15,21-24}$ They also arouse clinical interest related to the possible treatment of lung silicosis, and can be used as antimalarials and antibacterial agents. ${ }^{25}$ Deferoxamine B, a siderophore produced by microorganisms, has been recognized as a strong vanadium chelator. ${ }^{26}$

The present study examines the complexation equilibria for the iron(III) and oxidovanadium(IV) ions with 2-picolinehydroxamic acid (PicHA) (Fig. 1) in aqueous solution, which have not been described until now. Recent studies indicate that 2-picolininohydroxamic acid alone, as well coordinated by the cobalt(II) ion, exhibits antimicrobial properties, especially against Candida, Pseudomonas aeruginosa and Bacillus subtilis, and activates non-specific immune cells that indirectly promote the eradication of infection. ${ }^{27}$

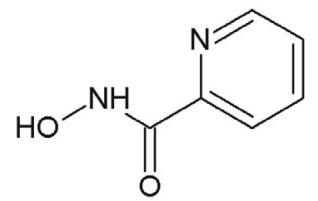

Fig. 1. The ligand 2-picolinehydroxamic acid structure (PicHA, LH).

\section{Experimental}

\section{1. Materials}

2-Picolinehydroxamic acid (PicHA) was synthesized by a team at the Department of Chemistry, National Taras Shevchenko University of Kiev, according to the procedure described in. ${ }^{28}$ Iron(III) chloride from Fluka and oxidovanadium(IV) sulfate oxide hydrate from Alfa Aeasar were used as standard solutions. The carbonate-free $1.0 \mathrm{~mol} \mathrm{~L}^{-1}$ $\mathrm{NaOH}$ solution, HPLC-grade water and methanol were purchased from J.T. Baker. Hydrochloric acid solution from Avantor Performance Materials was standardized alkalimetrically and determined by the Gran method. ${ }^{29}$ The standard solution of sodium chloride (Chempur) was used to adjust the ionic medium without further purification. Argon of high purity (Linde) was used.

\section{2. Spectrophotometric Measurements}

UV-Vis absorption spectra were recorded on a Cary 50 Bio spectrophotometer with the slit width of $1.5 \mathrm{~nm}$. The spectrophotometer was equipped with a fiber-optic device allowing simultaneous recording of spectrophotometric scans with $\mathrm{pH}$ values. Measurements were controlled by a Titrando 905 automatic titrator system (Metrohm) with a combined polymer microelectrode InLab Semi-Micro (METTLER TOLEDO). The fiber-optic probe, $5 \mathrm{~mm}$ long, corresponding to a path length of $1 \mathrm{~cm}$, was dipped directly into the thermostatted titration vessel. The electrode was calibrated with buffers at $\mathrm{pH} 4.00$ and 7.00 before use. All the experiments were accomplished in aqueous solution at a constant temperature of $25.0 \pm 0.1^{\circ} \mathrm{C}$ and ionic strength $I=1.0 \mathrm{~mol} \mathrm{~L}^{-1}$ adjusted by $\mathrm{NaCl}$. A stream of pure argon was passed over the surface of a 10 $\mathrm{mL}$ sample to obtain solutions free of oxygen and carbon dioxide. The $\mathrm{pH}$ values, changing after the addition of each base aliquot, were controlled by the Titrando 905 titrator and a time delay was given to equilibrate the system. The spectrum was recorded with a slow scan $\left(300 \mathrm{~nm} \mathrm{~min}^{-1}\right)$ at selected $\mathrm{pH}$ values.

The studies of $\mathrm{Fe}(\mathrm{III})$ complexation with PicHA were performed at ligand-to-metal molar ratios 4:1, 6:1 and 10:1 (total metal concentration of $5.0 \times 10^{-4} \mathrm{~mol} \mathrm{~L}^{-1}$ ). A large excess of ligand in relation to the metal ion was used to avoid precipitation from $\mathrm{Fe}$ (III) aqua-hydroxido complexes which could occur at a $\mathrm{pH}$ above $1 .^{30}$ Formation constants of the $\mathrm{Fe}(\mathrm{III})$ aqua-hydroxido complexes were determined under the same conditions as the complexation equilibria with the ligand. In turn, the titrations in the presence of $\mathrm{VO}(\mathrm{IV})$ were carried out at ligand-to-metal molar ratios 1:1 and 2:1 (at constant concentration of metal ions $\left.5.0 \times 10^{-3} \mathrm{~mol} \mathrm{~L}^{-1}\right)$. For $\mathrm{VO}(\mathrm{IV})$, under the present experimental conditions ( $\mathrm{pH}$ about 3 ), the hydroxylated forms could be neglected in comparison with the vanadyl aqua-ion. ${ }^{31,32}$ The initial $\mathrm{pH}$ appeared below 1.0 in all the experiments due to acidification by $1.0 \mathrm{~mol} \mathrm{~L}^{-1} \mathrm{HCl}$. The $\mathrm{pH}$ values in the range of $0.90-1.30$ were calculated directly from acid contents. The carbonate-free $1.0 \mathrm{~mol} \mathrm{~L}^{-1}$ $\mathrm{NaOH}$ was used as a titrant. Such a high concentration of the titrant was associated with necessity of neutralize a large excess of acid and avoid excessive dilution of the sample. The titrations were continued until precipitation.

The HypSpec program, part of the Hyperquad 2008 suite (Protonic Software) ${ }^{33}$ was used to calculate the molar absorption coefficients of the individual species and to determine the equilibrium constants resulting from spectrophotometric data. Overall concentration formation constants were calculated by a fitting procedure according to the formula: $\beta_{m l h}=\left[\mathrm{M}_{m} \mathrm{~L}_{l} \mathrm{H}_{h}\right] /[\mathrm{M}]^{m}[\mathrm{~L}]^{l}[\mathrm{H}]^{h}$. Based on these constants, the graphical simulation of the complex species distribution was carried out by HySS 2009. ${ }^{34}$

\section{3. Electrospray-Ionization Mass Spectrometry (ESI-MS) Measurements}

The ESI-MS and MS/MS spectra were recorded using a Varian 500-MS LC hexapole ion-trap mass spectrometer (Palo Alto, CA, USA). The study was performed for the ligand, as well as both iron(III) and oxidovanadium(IV) systems with PicHA in 50/50\% $(v / v)$ methanol/ water mixture without the addition of a background electrolyte. The ESI response is higher when methanol/water mixture is used because methanol provides a more stable spray and produces smaller initial droplets than water alone or highly aqueous solvent. ${ }^{35}$

The ligand spectra were determined at the concentration of $1.0 \times 10^{-2} \mathrm{~mol} \mathrm{~L}^{-1}$. For iron(III) - ligand system, the 
molar ligand-metal ratio was equal to $4: 1$ at the concentration of $\mathrm{Fe}(\mathrm{III})$ ion $2.5 \times 10^{-4} \mathrm{~mol} \mathrm{~L}^{-1}$. The spectra recorded in the presence of oxidovanadium(IV) and PicHA were carried out at a ligand-to-metal molar ratio 2:1 (concentration of $\mathrm{VO}(\mathrm{IV})$ ion $2.5 \times 10^{-3} \mathrm{~mol} \mathrm{~L}^{-1}$ ). The samples containing metal-ligand systems were adjusted to various $\mathrm{pH}$ values, selected for maximization formation of individual complexes (according to the species distribution graphs). The test samples were introduced into the ESI-MS source by continuous infusion using an instrument syringe pump at a rate of $10 \mu \mathrm{L} \mathrm{min}{ }^{-1}$. The ESI-source was operated at $5.00 \mathrm{kV}$ and the capillary heater was set to $350^{\circ} \mathrm{C}$. The cone voltage was within the range of $40-120 \mathrm{~V}$. The experiments were carried out in the positive and negative ion-mode.

\section{Results and Discussion}

\section{1. UV-Vis Spectra}

\section{1. 1. Fe(III) Complexes}

The electronic absorption spectra of PicHA in the presence of the iron(III) ion were recorded within the range of 300-800 nm (Fig. 2a). The tested $\mathrm{pH}$ range allowed for the maximum molar absorption coefficients and for the overall stability constants (Fig. 2b, Table 1) to be calculated by the HypSpec deconvolution procedure for the accepted $[\mathrm{FeL}]^{2+}$ and $\left[\mathrm{FeL}_{2}\right]^{+}$species (Fig. 3). The mixed hydroxido complexes with ligand, complexes with protonated ligand $[\mathrm{LH}]$, as well as the polynuclear complexes, observed for transition metal ion - PicHA systems, ${ }^{27,36,37}$ have not been confirmed in the equilibrium model during the refinement procedure. Dissociation constants of PicHA (Fig. 1) used in the model were taken from own data. ${ }^{27}$ The first step of ligand dissociation for $\left[\mathrm{LH}_{2}\right]^{+}$ form concerns the protonated pyridyl group $\left(\mathrm{p} K_{\mathrm{a} 1} 1.80\right)$ and the second one is assigned to the dissociation of the hydroxamic group proton $\left(\mathrm{p} K_{\mathrm{a} 1} 8.22\right)$ of the $[\mathrm{LH}]$ form. Molar absorption coefficients of iron(III) ion, calculated on the basis of the electronic absorption spectra (Fig. S1a,b), were used in HypSpec procedure. The hydrolysis of the iron(III) ion was already observed above $\mathrm{pH} 1$ (Fig. S1c). The separately determined formation constants of the aqua-hydroxido complexes: $[\mathrm{Fe}(\mathrm{OH})]^{2+}$ and $\left[\mathrm{Fe}(\mathrm{OH})_{2}\right]^{+}$were equal to $\log _{10} \beta_{10-1}=-2.68(2)$ and $\log _{10}$ $\beta_{10-2}=-6.48(10)$, respectively, and corresponded to the literature data. ${ }^{30,38-40}$ During the calculations, the potential polynuclear hydrolysis species $\left(\left[\mathrm{Fe}_{2}(\mathrm{OH})_{2}\right]^{4+}\right.$ or $\left.\left[\mathrm{Fe}_{3}(\mathrm{OH})_{4}\right]^{5+}\right)^{38}$ were not accepted by the HypSpec fitting procedure under the present experimental conditions. As indicated by the reference data, ${ }^{30,38}$ a low concentration of iron ions, adapted to the experiment, results in the trace amount or absence of polynuclear complexes in the solution. In addition, the presence of chloride ions and the way they form relatively strong complex with iron(III) affects the lower hydrolysis effect, especially in the formation of polynuclear complexes. ${ }^{38,41}$

The high stability constants values obtained in the Fe(III) - PicHA system (Table 1), correspond to the reference data for other hydroxamic acids ${ }^{22}$ and confirm the possibility of the formation of very stable iron(III) chelates with the ligand. Chelation in the $[\mathrm{FeL}]^{2+}$ species is possible by the oxygen atoms of the ligand, forming a stable five-membered ring (Fig. 3a), just as reported for X-ray crystal forms. ${ }^{21}$ Natural trihydroxamic acids also chelate the iron(III) ion using oxygen atoms, ${ }^{25}$ thus it could be assumed that the same coordination mode occurs for the $\left[\mathrm{FeL}_{2}\right]^{+}$complex (Fig. 3b) with a high value of the stepwise stability constant $\log 10 K_{\mathrm{FeL}_{2}}^{\mathrm{FeL}}=9.93$ (base on Table 1 and theoretically supported in the literature $\left.{ }^{42,43}\right)$. The distribution curves of the complex species as a function of $\mathrm{pH}$ are shown in Fig. 4. a)

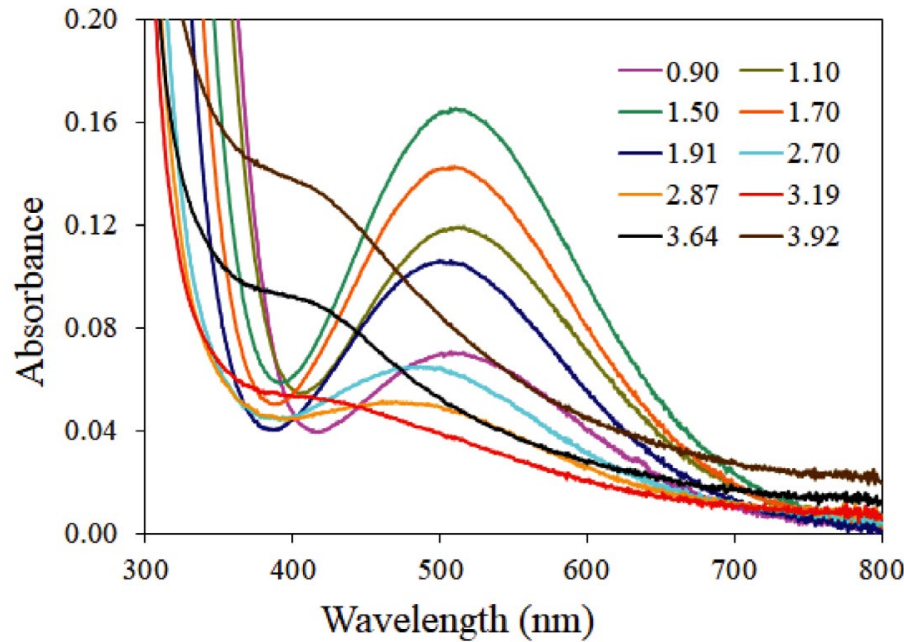

b)

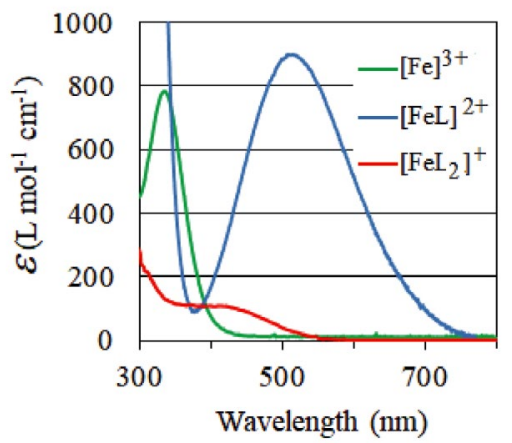

Fig. 2. (a) UV-Vis absorption spectra of the Fe(III) - PicHA system at ligand-to-metal molar ratio $4: 1$, within the pH range $0.90-3.92 ; c_{\mathrm{Fe}(\mathrm{III})}=5.0 \times$ $10^{-4} \mathrm{~mol} \mathrm{~L}^{-1}$. (b) Molar absorption coefficients for the complexes in the Fe(III) - PicHA system. 
a)

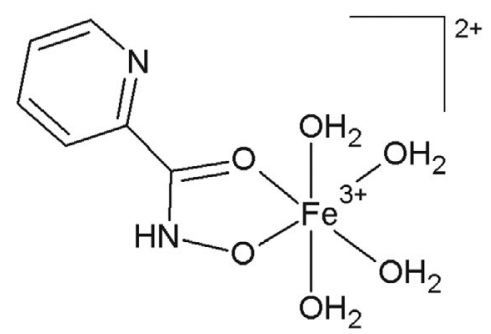

b)<smiles>C[C+](C)C[P+]1(O)ONC(=O)O[Pb]1(O)ONC(=O)c1ccccn1</smiles>

Fig. 3. Suggested coordination modes in the Fe(III) - PicHA system: (a) $[\mathrm{FeL}]^{2+},(\mathbf{b})\left[\mathrm{FeL}_{2}\right]^{+}$.

Table 1. Decimal logarithms of overall formation constants $\beta_{m l h}=$ $\left[\mathrm{M}_{m} \mathrm{~L}_{l} \mathrm{H}_{h}\right] /[\mathrm{M}]^{m}[\mathrm{~L}]^{l}[\mathrm{H}]^{h}$ at $25.0 \pm 0.1{ }^{\circ} \mathrm{C}, I=1.0(\mathrm{NaCl})$ and UV-Vis spectral data; standard deviations in parentheses after overall stability constants refer to random errors only

\begin{tabular}{lcc}
\hline Species & $\log _{10} \beta_{\text {mlh }}$ & $\lambda_{\text {max }}\left(\varepsilon_{\max }\right)$ \\
\hline$[\mathrm{FeL}]^{2+}$ & $10.25(1)$ & $509(897)$ \\
{$\left[\mathrm{FeL}_{2}\right]^{+}$} & $20.18(1)$ & $420^{\text {sh }}(107)$ \\
$\sigma^{\mathrm{a}}$ & 0.003 & \\
\hline$[\mathrm{VOL}]^{+}$ & $7.64(1)$ & $500^{\mathrm{sh}}(704)$ \\
$\sigma^{\mathrm{a}}$ & 0.076 & \\
\hline
\end{tabular}

${ }^{\mathrm{a}} \sigma-$ the value of the normalized sum of squared residuals

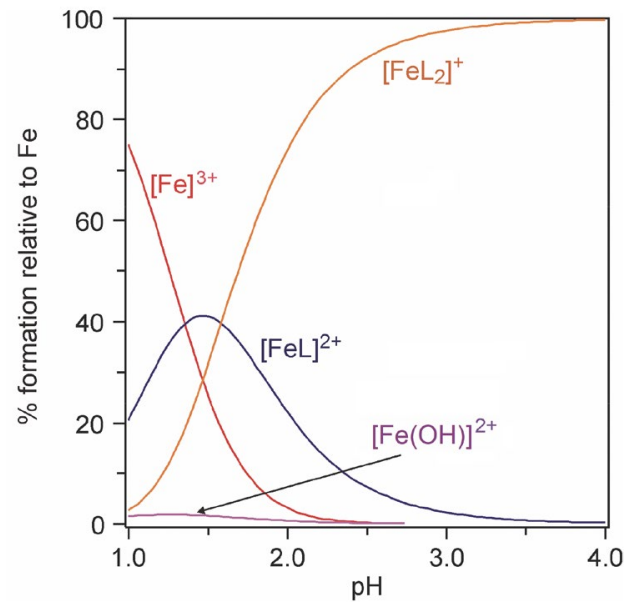

Fig. 4. Species distribution curves as a function of $\mathrm{pH}$ for the complexes formed in the $\mathrm{Fe}(\mathrm{III})$ - PicHA system at 4:1 ligand-to-metal molar ratio, $c_{\mathrm{Fe}(\mathrm{III})}=5.0 \times 10^{-4} \mathrm{~mol} \mathrm{~L}^{-1}$.

As it follows from Fig. 2a, the Fe(III) complexes are formed already in a very acidic medium (below $\mathrm{pH} 1.0$ ) just at the beginning of titrations. This is demonstrated by the presence of the absorption band at ca. $510 \mathrm{~nm}$, characteristic of octahedral coordination of $\mathrm{Fe}$ (III) with one hydroxamic acid molecule, ${ }^{16,21,22}$ and confirmed by the species distribution graph (Fig. 4). The presence of ligand-to-metal charge transfer absorption bands, often obscuring the low intensity $d$ - $d$ absorption, is characteristic of the iron(III) interaction. ${ }^{44}$ During the titration, the intensity of this absorption band increased, reaching the maximum absorbance at $\mathrm{pH}$ 1.5. However, as the $\mathrm{pH}$ in- creased further, the band decreased with a blue shift to 470 $\mathrm{nm}$ at $\mathrm{pH}$ about 2.9. This was connected with the simultaneous existence of the two forms: a decrease of the $[\mathrm{FeL}]^{2+}$ concentration and formation of $\left[\mathrm{FeL}_{2}\right]^{+}$species (Fig. 4). A blue shift of the molar absorption coefficients of $\left[\mathrm{FeL}_{2}\right]^{+}$in relation to $[\mathrm{FeL}]^{2+}$ was also observed for other hydroxamic acid complexes with metal ions. ${ }^{9,15,26}$ A slight decrease of the complex stability (Table 1) most likely occurred due to an increase of the ligand field.

As shown in Fig. 4, a small share (about $2 \%$ of the total iron) of the $[\mathrm{Fe}(\mathrm{OH})]^{2+}$ complex is observed in solution at the initial $\mathrm{pH}$ range. Moreover, $509 \mathrm{~nm}$ corresponds to the maximum molar absorption coefficient of the $[\mathrm{FeL}]^{2+}$ species (Table 1, Fig. 2). At this wavelength, the aqua-hydroxido complex shows a molar absorption coefficient value of almost ten times lower (Fig. S1) than the iron(III) complex with one PicHA molecule.

Further alkalization caused the formation of a shoulder at $370-450 \mathrm{~nm}$ at the $\mathrm{pH}$ above 3.19 (Fig. 2a), and the change of color from pale pink to orange, reasonably correlated with increasing share of the $\left[\mathrm{FeL}_{2}\right]^{+}$complex. According to the species distribution curves, this $\mathrm{pH}$ range corresponded to reaching almost $100 \%$ share of $\left[\mathrm{FeL}_{2}\right]^{+}$in the solution (Fig. 4). An increase of $\mathrm{pH}$ above 4 caused a disturbance in the UV-Vis absorption spectra by light scattering arising from poorly soluble hydrolytic products.

After the precipitation (at $\mathrm{pH}$ approximately 4.0 ), the mixture was again acidified to $\mathrm{pH}$ below 1.50 . Then the absorption band at ca. $510 \mathrm{~nm}$, characteristic of $[\mathrm{FeL}]^{2+}$ was observed again. This indicated the possible partial reversibility of the complexes in $\mathrm{Fe}(\mathrm{III})$ - PicHA system and allowed the authors to assume that some of the iron(III) aqua-ions were released into the solution (Fig. 4), by that indicating the siderophoric character of PicHA.

\section{1. 2. VO(IV) Complexes}

UV-Vis absorption spectra obtained for the VO(IV) - PicHA system indicate the complex formation starting from $\mathrm{pH}$ below 1.0 (Fig. 5a). Beside the $d$ - $d$ bands relative to the $\mathrm{VO}(\mathrm{IV})$ aqua-ion, $763 \mathrm{~nm}(e=13.4)$ and the shoulder $625 \mathrm{~nm}(e=6.0)$, an additional rising $d-d$ transition at about $500 \mathrm{~nm}$ was observed (Fig. 5b,c). Three intra $d$ shell electronic transitions are typical of $C_{4 \mathrm{v}}$ square pyramidal structure at the vanadyl ion. ${ }^{44}$ Further alkalization led to in- 
a)

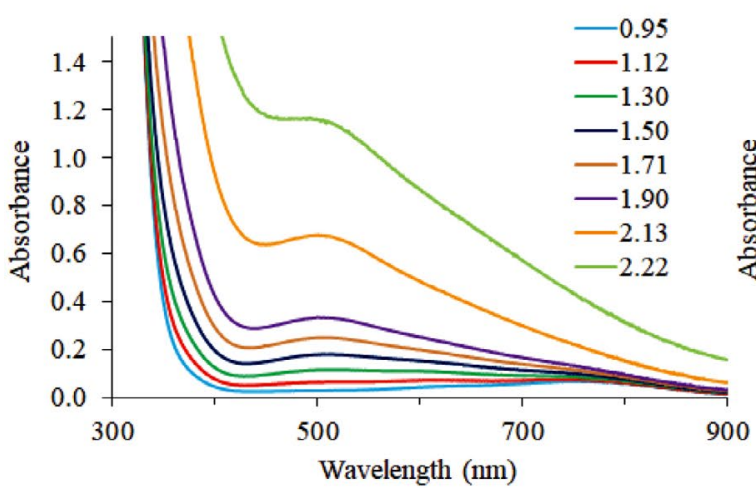

b)

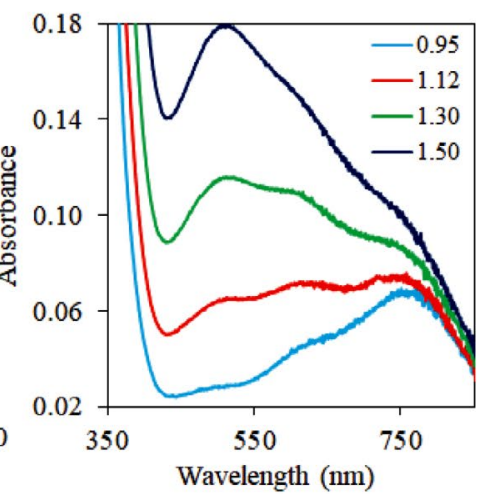

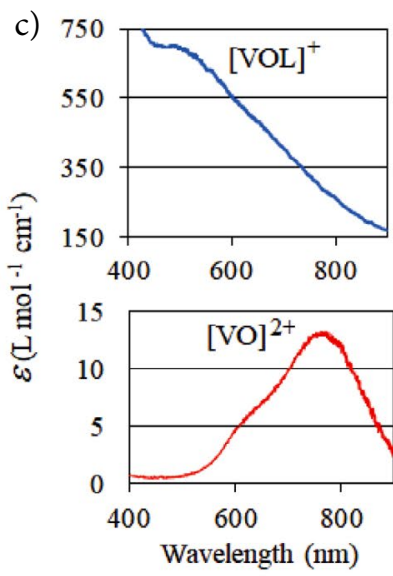

Fig. 5. UV-Vis absorption spectra of the $\mathrm{VO}(\mathrm{IV})$ - PicHA system at ligand-to-metal molar ratio $2: 1, c_{\mathrm{VO}(\mathrm{IV})}=5.0 \times 10^{-3} \mathrm{~mol} \mathrm{~L}^{-1}$ within the $\mathrm{pH}$ range (a) 0.95-2.22, (b) 0.95-1.50 - narrowed part of spectra. (c) Molar absorption coefficients for the complexes in the VO(IV) - PicHA system.

creased intensity of the transition bands, up to precipitation (at $\mathrm{pH}$ 2.2). Due to the low $\mathrm{pH}$ values, precipitation is most likely not connected with the aqua-hydroxido complexes of $\mathrm{VO}(\mathrm{IV}),{ }^{31,32}$ but rather with low water solubility of subsequent species formed in the VO(IV) - PicHA system.

During the first titration step within the $\mathrm{pH}$ range of 0.95-1.90 (Fig. 5a), the increase of absorbance was concomitant with a small wavelength change (the differences were within the slit width value). This most likely indicates the formation of only one VO(IV) complex with the PicHA molecule in the equilibrium solution.

The stability constant and the maximum molar absorption coefficient of the $[\mathrm{VOL}]^{+}$complex has been determined based on the spectrophotometric titrations of the VO(IV) - PicHA system (Table 1, Fig. 5c). The calculations also indicated the possible formation of $\left[\mathrm{VOL}_{2}\right]$. Unfortunately, the values of the molar absorption coefficients were affected by high errors due to low participation of this complex in the equilibrium solution. This induced the rejection of $\left[\mathrm{VOL}_{2}\right]$ from the equilibrium model. As previously observed for the Fe(III) - PicHA system, ${ }^{22}$ the stabil-

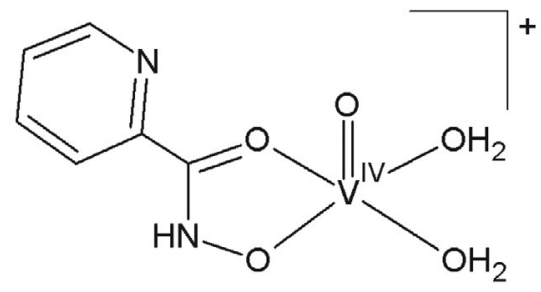

Fig. 6. Suggested coordination mode of $[\mathrm{VOL}]^{+}$in the $\mathrm{VO}(\mathrm{IV})-$ PicHA system.

ity constant value of the $[\mathrm{VOL}]^{+}$is of the same order of magnitude as the reference data for other hydroxamic acid species. ${ }^{17}$ The literature EPR study ${ }^{17}$ as well as high value of the present stability constant indicate the chelated nature of the $[\mathrm{VOL}]^{+}$complex in $\left\{\mathrm{O}^{-} \mathrm{O}^{-}\right\}$mode (see Fig. 6).
Presumably, this complex forms pentacoordinated species, as suggested by DFT calculations carried out for acetohydroxamic acid. ${ }^{9}$ Moreover, as shown in ${ }^{44}$ a very strong $\mathrm{V}=\mathrm{O}$ axial bond is exceptionally short as compared to the equatorial bonds.

The $[\mathrm{VOL}]^{+}$complex confirmed is represented in the species distribution curves (Fig. 7). The VO(IV) aqua-ion was the dominant form in the system whereas $[\mathrm{VOL}]^{+}$was formed at a $\mathrm{pH}$ above 1 , reaching only $18 \%$ of the total vanadium at a $\mathrm{pH}$ of 2.2 .

Similarly to the Fe(III) - Picha system, in order to check the reversibility of the interaction between oxidovanadium(IV) and the ligand, the samples were acidified from $\mathrm{pH} 2.5$ to $\mathrm{pH}$ below 1 . The absorbance decreased at about $500 \mathrm{~nm}$ and the color changed from brown to transparent, which confirmed the reversible dissociation of the complexes, such as previously observed in the VO(IV) deferoxamine B system. ${ }^{26}$

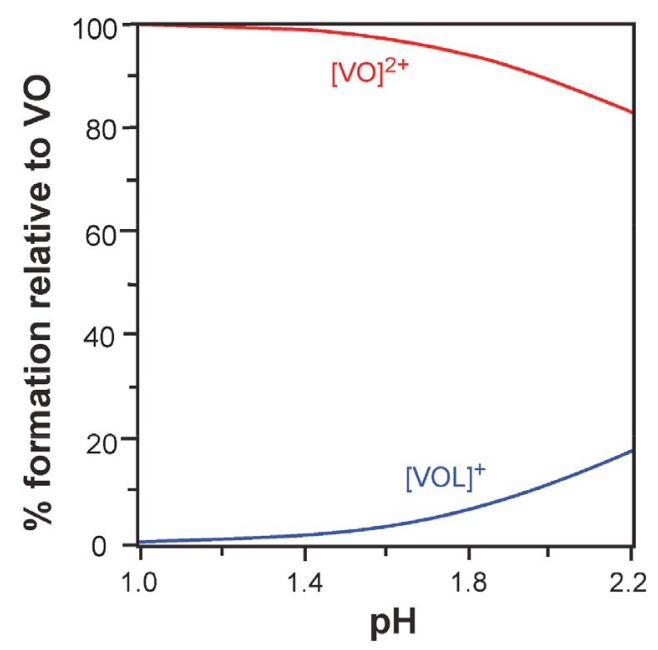

Fig. 7. Species distribution curves as a function of $\mathrm{pH}$ for the complexes formed in VO(IV) - PicHA system at 2:1 ligand-to-metal molar ratio, $c_{\mathrm{VO}(\mathrm{IV})}=5.0 \times 10^{-3} \mathrm{~mol} \mathrm{~L}^{-1}$. 


\section{2. ESI-MS Results}

ESI-MS spectra were taken of PicHA as well as of its systems with $\mathrm{Fe}(\mathrm{III})$ and VO(IV). Structural investigation by the tandem mass spectrum (Fig. S2) of the protonated ligand molecule $\left[\mathrm{LH}_{2}\right]^{+}(\mathrm{m} / z=139.0)$ (Fig. 1) indicated the possibility of its degradation. The first step $(\mathrm{m} / z=$ 138.0) was related to the loss of hydrogen atom, most likely from pyridine group $-\mathrm{NH}^{+}$, as indicated by potentiometric studies. ${ }^{27}$ Detachment of $-\mathrm{NH}_{\text {hydroxamic }}$ from $\left[\mathrm{LH}_{2}\right]^{+}$, probably due to rearrangement of the molecule, gave the ion with $m / z=124.0$. Then the ion with $\mathrm{m} / z=$ 122.0 was formed by the loss of hydrogen atoms. The competitive fragmentation of $\left[\mathrm{LH}_{2}\right]^{+}$involved the loss of $\mathrm{H}_{2} \mathrm{O}(\mathrm{m} / z=121.0)$, probably by the intramolecular migration of a pyridine hydrogen to $-\mathrm{OH}$ group. As a result of further fragmentation, peaks $m / z=106.0$ and $\mathrm{m} / z=$ 78.0 were obtained. The first was formed after the detachment of $\mathrm{NH}_{\text {hydroxamic }}$, the second $\mathrm{C}=\mathrm{O}$, respectively.

The structural analysis of both PicHA systems used negative- and positive-ion mass spectra. The ESI-MS spectra of Fe(III) - PicHA complexes were taken at three $\mathrm{pH}$ values $(1.6,3.2,6.5)$. The use of the $50 / 50 \%(\mathrm{v} / \mathrm{v})$ methanol/water mixture resulted in precipitation at $\mathrm{pH}$ about 7.0, higher than in spectrophotometric measurements, probably due to the stabilizing properties of methanol. ${ }^{45}$ At $\mathrm{pH} 1.6$, the negative-ion spectrum of the $[\mathrm{Fe}(\mathrm{III}) \mathrm{L}+2 \mathrm{Cl}$ $+\mathrm{OH}]^{-}(m / z=280.0)$ and the adduct of Fe(III) $(m / z=$ 256.0) containing the fragment ion $m / z=78.0$ were registered (Fig. S3). The $m / z$ values for all ions in the paper were related to the stable isotopes ${ }^{56} \mathrm{Fe}$ and ${ }^{35} \mathrm{Cl}$. Moreover, $[\mathrm{Fe}(\mathrm{III})+4 \mathrm{Cl}]^{-}(m / z=196.0)$ was also detected, which confirms a share of iron(III) aqua-ions in very acidic medium (cf. Fig. 4). Alkalization to $\mathrm{pH} 3.2$ led to an appearance of further complexes with one PicHA molecule. This concerned both the negative adduct of $\mathrm{Fe}(\mathrm{II})(\mathrm{m} / z=269.0)$ with the fragment ion $m / z=122.0$ (Fig. S4a) and the positive adducts/associate of $\mathrm{Fe}(\mathrm{II})(\mathrm{m} / z=197.0 ; 255.0)$ with the fragment ion $m / z=106.0$ (Fig. S4b). The reduction process of $\mathrm{Fe}(\mathrm{III})$ to the $\mathrm{Fe}(\mathrm{II})$ state is most probable in ESI-MS measurements. ${ }^{46,47}$ The formation of the [Fe(III) $\left.\mathrm{L}_{2}\right]^{+}$complex $(m / z=330.0)$, confirmed by the species distribution curves (Fig. 4), was also shown in Fig. S4b. A further $\mathrm{pH}$ increase (to 6.5) affected a number of signals of bi-ligand complexes (Fig. S5); [Fe(II)L ${ }^{+}(m / z=271.0)$ with the fragment ion $m / z=78.0$, the $\mathrm{Cl}^{-}$adduct of $\mathrm{Fe}(\mathrm{II})$ $(m / z=303.0)$ with two fragment ions $m / z=106.0$ and its associate $(m / z=606.0)$ were detected. Interestingly, the ESI-MS studies showed the presence of iron complexes with three PicHA molecules: [Fe(III) $\left.\mathrm{L}_{3}+\mathrm{Na}+2 \mathrm{Cl}\right]^{-}(\mathrm{m} / z$ $=560.0)$ in Fig. S5a, $\left[\mathrm{Fe}(\mathrm{III}) \mathrm{L}_{3}+\mathrm{H}\right]^{+}(m / z=468.0)$ and $\left[\mathrm{Fe}(\mathrm{III}) \mathrm{L}_{3}+2 \mathrm{Na}+\mathrm{Cl}\right]^{+}(m / z=548.0)$ in Fig. S5b. This was possible due to the achievement of a higher $\mathrm{pH}$ values than in spectrophotometric studies (Fig. 2a).

The ESI-MS spectra for the VO(IV) - PicHA system were performed in the positive and negative ion mode at pH 1.4 and 2.6. Nevertheless, no significant signal was ob- served in the negative ion mode. According to the spectrophotometric data (Fig. 7), mainly $\mathrm{VO}^{2+}$ aqua-ions were observed at $\mathrm{pH}$ 1.4. This has been confirmed by a high relative intensity signal for $\left[\mathrm{VO}+\mathrm{SO}_{4}+\mathrm{H}\right]^{+}(\mathrm{m} / z=164.0)$ (Fig. S6) as well as the high abundance of the ligand alone and its fragment ions, which were observed in the tandem mass spectrum of the $\left[\mathrm{LH}_{2}\right]^{+}$(Fig. S2). However, a number of signals for the VO(IV) - PicHA complexes with one ligand molecule has been identified, as adducts: [VOL + $\left.\mathrm{H}_{2} \mathrm{O}+\mathrm{CH}_{3} \mathrm{OH}\right]^{+}(m / z=254.0),[\mathrm{VOL}+\mathrm{NaOH}+\mathrm{NaCl}+$ $\left.\mathrm{CH}_{3} \mathrm{OH}\right]^{+}(m / z=334.0),[\mathrm{VO}+\mathrm{Cl}]^{+}(m / z=224.0)$ with the fragment ion $m / z=122.0$ and associates: $\left[(\mathrm{VO})_{2} \mathrm{~L}+\right.$ $\left.\mathrm{SO}_{4}\right]^{+}(\mathrm{m} / \mathrm{z}=445.0)$ with the fragment ion $\mathrm{m} / z=78.0$ and $\left[(\mathrm{VO})_{2} \mathrm{~L}_{2}+\mathrm{SO}_{4}+\mathrm{NaOH}+\mathrm{Na}\right]^{+}(\mathrm{m} / \mathrm{z}=567.0)$. In addition, there were PicHA complexes formed in a ratio of 2:1 with oxidovanadium(IV), confirmed by signals of low relative intensity: $\left[\mathrm{VOL}_{2}+\mathrm{Na}\right]^{+}(m / z=364.0)$ and others $(m / z=282.0 ; 326.0)$ with fragment ions $m / z=78.0$ and 122.0 (see Fig. S6). Further alkalization was carried out to $\mathrm{pH}$ 2.6, without precipitation in the methanol/water mixture, in contrast to the aqueous solution, where precipitation appeared at $\mathrm{pH}$ above 2.22. This enabled the identification of new $\mathrm{VO}(\mathrm{IV})$ complexes with one or two ligand molecules in the system: [VOL] ${ }^{+}(m / z=204.0)$, [VOL + $\left.\mathrm{H}_{2} \mathrm{O}\right]^{+}(m / z=222.0)$, [VOL $\left.+2 \mathrm{H}_{2} \mathrm{O}\right]^{+}(m / z=240.0)$ in Fig. $\mathrm{S} 7 \mathrm{a},\left[\mathrm{VOL}+\mathrm{H}_{2} \mathrm{SO}_{4}\right]^{+}(m / z=302.0),\left[\mathrm{VOL}_{2}+\mathrm{H}\right]^{+}(m / z=$ 342.0), $\left[\mathrm{VOL}_{2}+\mathrm{Na}+\mathrm{H}_{2} \mathrm{O}\right]^{+}(m / z=382.0)$ Fig. S7b. In addition, various forms of the ligand, such as $[\mathrm{LH}+\mathrm{Na}+$ $\mathrm{HCl}]^{+}$ion $(m / z=197.0)$ and others observed in the tandem mass spectrum (Fig. S2), have been demonstrated.

\section{Conclusions}

The UV-Vis electronic spectroscopy method was used to determine the stability and molecular formula of the 2-picolinehydroxamic acid complexes with $\mathrm{Fe}(\mathrm{III})$ as well as VO(IV). The ligand showed more effective binding to iron(III) than oxidovanadium(IV), indicating formation of $\mathrm{ML}$ and $\mathrm{ML}_{2}$ metal-ligand species and higher values of formation constants for the first metal ion. The 2-picolinehydroxamic acid was found to have a tendency to form complexes coordinated in the $\left\{\mathrm{O}_{\mathrm{O}} \mathrm{O}^{-}\right\}$mode. The formation of mononuclear iron(III) and oxidovanadium(IV) complexes with 2-picolinehydroxamic acid was also confirmed at various $\mathrm{pH}$ levels by means of ESI-MS studies, despite the necessity of using another solvent (methanol/ water) than in spectrophotometric measurements. During the latter measurements, the presence of methanol in the mixture probably stabilized the complex structures, causing the formation of precipitation at a higher $\mathrm{pH}$ than in an aqueous solution. This allowed the ESI-MS spectra to suggest subsequent types of complexes in both metal systems.

The tested complexes with Fe(III) and VO(IV) offer the advantage of reversibility to the aqua-ion and ligand 
alone. This may indicate the siderophoric character of $\mathrm{Pi}$ cHA and confirm a lack of oxidation of the VO(IV) ion to $\mathrm{V}(\mathrm{V})$ under the conditions of the experiment. Our research provides information for the interaction of PicHA with two biologically important metal ions in aqueous solution. The knowledge of complexation equilibria may enhance the understanding of the mechanism of siderophore action and increase protection against excess of toxic metal ions.

\section{Conflict of Interest}

The authors declare that they have no conflicts of interest.

\section{Acknowledgements}

This work was supported by the Medical University of Lodz [Statute Fund No. 503/3-014-02/503-31-001]. We offer our thanks to Prof. Igor O. Fritsky and Dr. Irina A. Golenya (Department of Chemistry, National Taras Shevchenko University of Kiev) for the synthesis of 2-picolinehydroxamic acid.

\section{Supplementary material}

Supplementary electronic absorption spectra, molar absorption coefficients and species distribution curves for the $\mathrm{Fe}(\mathrm{III})$ aqua-hydroxido complexes (Fig. S1) as well as mass spectra (Figs. S2-S7) can be found here.

\section{References}

1. I. Correia, P. Adão, S. Roy, M. Wahba, C. Matos, M. R. Maurya, F. Marques, F. R. Pavan, C. Q. F. Leite, F. Avecilla, J. C. Pessoa, J. Inorg. Biochem. 2014, 141, 83-93.

DOI:10.1016/j.jinorgbio.2014.07.019

2. C. Karami, A. Alizadeh, M. A. Taher, Z. Hamidi, B. Bahrami, J. Appl. Spectrosc. 2016, 83, 687-693.

DOI:10.1007/s10812-016-0349-3

3. A. Bazmandegan-Shamili, A. M. Haji Shabani, S. Dadfarnia, M. Saeidi, M. Rohani Moghadam, Turk. J. Chem. 2015, 39, 1059-1068. DOI:10.3906/kim-1504-9

4. C. C. McLauchlan, H. A. Murakami, C. A. Wallace, D. C. Crans, J. Inorg. Biochem. 2018, 186, 267-279.

DOI:10.1016/j.jinorgbio.2018.06.011

5. D. C. Crans, K. A. Woll, K. Prusinskas, M. D. Johnson, E. Norkus, Inorg. Chem. 2013, 52, 12262-12275.

DOI:10.1021/ic4007873

6. B. Monzyk, A. L. Crumbliss, J. Am. Chem. Soc. 1982, 104, 4921-4929. DOI:10.1021/ja00382a031

7. E. Farkas, H. Csóka, G. Micera, A. Dessi, J. Inorg. Biochem. 1997, 65, 281-286. DOI:10.1016/S0162-0134(96)00144-4

8. D. N. Chasteen, The biochemistry of vanadium. In: Copper, Molybdenum, and Vanadium in Biological Systems. Struc- ture and Bonding. Springer, Berlin, Heidelberg, 1983, pp. 105-138. DOI:10.1007/BFb0111304

9. J. M. Da Silva Santos, S. Carvalho, E. B. Paniago, H. A. Duarte, J. Inorg. Biochem. 2003, 95, 14-24.

DOI:10.1016/S0162-0134(03)00072-2

10. E. D. Carpio, L. Hernández, C. Ciangherotti, V. V. Coa, L. Jiménez, V. Lubes, G. Lubes, Coord. Chem. Rev. 2018, 372, 117-140. DOI:10.1016/j.ccr.2018.06.002

11. J. C. Pessoa, S. Etcheverry, D. Gambino, Coord. Chem. Rev. 2015, 301-302, 24-48. DOI:10.1016/j.ccr.2014.12.002

12. K. H. Thompson, J. Lichter, C. LeBel, M. C. Scaife, J. H. McNeill, C. Orvig, J. Inorg. Biochem. 2009, 103, 554-558. DOI:10.1016/j.jinorgbio.2008.12.003

13. H. Sakurai, Y. Kojima, Y. Yoshikawa, K. Kawabe, H. Yasui, Coord. Chem. Rev. 2002, 226, 187-198. DOI:10.1016/S0010-8545(01)00447-7

14. L. J. Hernández-Benítez, P. Jiménez-Cruz, K. E. Cureño-Hernández, A. Solano-Peralta, M. Flores-Álamo, A. Flores-Parra, I. Gracia-Mora, S. E. Castillo-Blum, Inorg. Chim. Acta. 2018, 480, 197-206. DOI:10.1016/j.ica.2018.05.013

15. P. Buglyó, E. M. Nagy, I. Sóvágó, A. Ozsváth, D. Sanna, E. Farkas, Polyhedron 2016, 110, 172-181.

DOI:10.1016/j.poly.2016.02.031

16. E. Farkas, E. Kozma, M. Petho, K. M. Herlihy, G. Micera, Polyhedron 1998, 17, 3331-3342.

DOI:10.1016/S0277-5387(98)00113-2

17. P. Buglyó, N. Pótári, Polyhedron 2005, 24, 837-845. 7

18. B. Monzyk, A. L. Crumbliss, J. Am. Chem. Soc. 1979, 101, 6203-6213. DOI:10.1021/ja00515a009

19. C. D. Hardy, A. Butler, J. Biol. Inorg. Chem. 2018, 23, 957-967. DOI:10.1007/s00775-018-1584-2

20. T. Lifa, W. Tieu, R. K. Hocking, R. Codd, Inorg. Chem. 2015, 54, 3573-3583. DOI:10.1021/acs.inorgchem.5b00141

21. D. A. Brown, D. McKeith (nee Byrne), W. K. Glass, Inorg. Chim. Acta. 1979, 35, 5-10. DOI:10.1016/S0020-1693(00)93409-1

22. N. Gálvez, B. Ruiz, R. Cuesta, E. Colacio, J. M. Domínguez-Vera, Inorg. Chem. 2005, 44, 2706-2709

DOI:10.1021/ic048840s

23. D. Cheshmedzhieva, N. Toshev, M. Gerova, O. Petrov, T. Dudev, J. Mol. Model. 2018, 24:114. DOI:10.1007/s00894-018-3651-6

24. H. Wen, Y. Qin, W. Zhong, C. Li, X. Liu, Y. Shen, Enzyme Microb. Technol. 2016, 92, 9-17.

DOI:10.1016/j.enzmictec.2016.06.006

25. M. T. Caudle, A. L. Crumbliss, Inorg. Chem. 1994, 33, 40774085. DOI:10.1021/ic00096a037

26. P. Buglyó, N. Culeddu, T. Kiss, G. Micera, D. Sanna, J. Inorg. Biochem. 1995, 60, 45-59.

DOI:10.1016/0162-0134(95)00001-5

27. M. Woźniczka, M. Świątek, M. Pająk, J. Gądek-Sobczyńska, M. Chmiela, W. Gonciarz, P. Lisiecki, B. Pasternak, A. Kufelnicki, J. Inorg. Biochem. 2018, 187, 62-72.

DOI:10.1016/j.jinorgbio.2018.07.010

28. J. B. Hynes, J. Med. Chem. 1970, 13, 1235-1237. DOI:10.1021/jm00300a056 
29. P. Gans, B. O’Sullivan, Talanta 2000, 51, 33-37.

DOI:10.1016/S0039-9140(99)00245-3

30. J. Torres, S. Domínguez, M. F. Cerdá, G. Obal, A. Mederos, R. F. Irvine, A. Díaz, C. Kremer, J. Inorg. Biochem. 2005, 99, 828-840. DOI:10.1016/j.jinorgbio.2004.12.011

31. D. C. Crans, J. J. Smee, E. Gaidamauskas, L. Yang, Chem. Rev. 2004, 104, 849-902. DOI:10.1021/cr020607t

32. M. Jansson-Charrier, E. Guibal, J. Roussy, B. Delanghe, P. Le Cloirec, Wat. Res. 1996, 30, 465-475.

DOI:10.1016/0043-1354(95)00154-9

33. P. Gans, A. Sabatini, A. Vacca, Talanta 1996, 43, 1739-1753. DOI:10.1016/0039-9140(96)01958-3

34. L. Alderighi, P. Gans, A. Ienco, D. Peters, A. Sabatini, A. Vacca, Coord. Chem. Rev. 1999, 184, 311-318. DOI:10.1016/S0010-8545(98)00260-4

35. R. Kostiainen, T. J. Kauppila, J. Chromatogr. A 2009, 1216, 685-699. DOI:10.1016/j.chroma.2008.08.095

36. L. Marchiò, N. Marchetti, C. Atzeri, V. Borghesani, M. Remellib, M. Tegoni, Dalton Trans. 2015, 44, 3237-3250.

DOI:10.1039/C4DT03264K

37. E. Gumienna-Kontecka, I. A. Golenya, A. Szebesczyk, M. Haukka, R. Krämer, I. O. Fritsky, Inorg. Chem. 2013, 52, 7633-7644. DOI:10.1021/ic4007229
38. G. H. Khoe, P. L. Brown, R. N. Sylva, R. G. Robins, J. Chem. Soc., Dalton Trans. 1986, 1901-1906. DOI:10.1039/DT9860001901

39. M. Iuliano, G. De Tommaso, J. Chem. Eng. Data 2010, 55, 400-404. DOI:10.1021/je900394c

40. W. N. Perera, G. Hefter, Inorg. Chem. 2003, 42, 5917-5923. DOI:10.1021/ic034087b

41. R. N. Collins, K. M. Rosso, A. L. Rose, C. J. Glover, T. D. Waite, Geochim. Cosmochim. Acta 2016, 177, 150-169. DOI:10.1016/j.gca.2016.01.021

42. A. E. Martell, R. D. Hancock, Metal complexes in aqueous solutions, Springer Science+ Business Media, New York 1996. DOI:10.1007/978-1-4899-1486-6

43. A. E. Martell, R. J. Motekaitis, Determination and use of stability constants, second ed., VCH Publishers, Inc., New York 1992.

44. A. B. P. Lever, Inorganic electronic spectroscopy, second ed. Elsevier, Amsterdam 1984.

45. M. Tegoni, M. Remelli, Coord. Chem. Rev. 2012, 256, 289315. DOI:10.1016/j.ccr.2011.06.007

46. G. Weber, N. von Wirén, H. Hayen, Rapid Commun. Mass Spectrom. 2006, 20, 973-980. DOI:10.1002/rcm.2402

47. H. Neubert, R. C. Hider, D. A. Cowan, Rapid Commun. Mass Spectrom. 2002, 16, 1556-1561. DOI:10.1002/rcm.756

\section{Povzetek}

Z UV-Vis spektrofotometričnimi metodami smo določili kompleksacijske lastnosti 2-pikolinhidroksamske kisline za vezavo na železove(III) in oksidovanadijeve(IV) ione v vodnih raztopinah. Speciacijske modele smo potrdili in razširili z masno spektrometrijo z ionizacijo z elektrorazprševanjem (ESI-MS). Pri obeh sistemih nastanejo enojedrni kompleksi pri vrednostih $\mathrm{pH}$ pod $1 \mathrm{~s}$ kelatno koordinacijo $\left\{\mathrm{O}_{\mathrm{O}} \mathrm{O}^{-}\right\}$, ki vodi do nastanka petčlenskega obroča. Določili smo vrednosti stabilizacijskih konstant in jih primerjali s sorodnimi sistemi, ki kažejo na bolj učinkovito vezavo liganda $\mathrm{s} F e(\mathrm{III}) \mathrm{v}$ primerjavi z VO(IV). Kisel medij v sistemu VO(IV) - 2-pikolinhidroksamska kislina preprečuje oksidacijo VO(IV) v V(V). 2-Pikolinhidroksamska kislina je bila izbrana zaradi predhodno potrjenih bioloških lastnosti. Kot posledica nakisanja smo opazili reverzibilno disociacijo kompleksa v obeh sistemih, kar kaže, da bi lahko bila 2-pikolinhidroksamska kislina potencialni siderofor.

Except when otherwise noted, articles in this journal are published under the terms and conditions of the Creative Commons Attribution 4.0 International License 